\title{
Productivity, chemical composition and ruminal degradability of irrigated Napier grass leaves harvested at three stages of maturity
}

\author{
M.D. Rambau, F. Fushai \& J.J. Baloyi ${ }^{\#}$ \\ Department of Animal Science, University of Venda, Bag X5050, Thohoyandou, 0950, South Africa
}

(Received 18 March 2016; Accepted 30 September 2016; First published online 19 November 2016)

\author{
Copyright resides with the authors in terms of the Creative Commons Attribution 2.5 South African Licence. See: \\ $\mathrm{http}: / /$ creativecommons.org/licenses/by/2.5/za/ \\ Condition of use: The user may copy, distribute, transmit and adapt the work, but must recognise the authors and the South \\ African Journal of Animal Science.
}

\begin{abstract}
The effect of the stage of maturity on the productivity, chemical composition, and ruminal degradability of Napier grass (Pennisetum purpureum) leaves under irrigation was studied. Samples were collected at three stages of maturity, at intervals of four weeks starting from the fourth week until the twelfth week (AprilJuly) after sprouting and then harvested to determine biomass. The stages of maturity had significant effects on longest leaf length per plant and plant height, but had no effect on number of leaves per plant and number of tillers. Dry matter (DM) increased significantly with maturity, while crude protein (CP) and fat content decreased significantly, with no significant effect on acid detergent lignin (ADL), ash, acid detergent fibre (ADF) and neutral detergent fibre (NDF). Maturity significantly decreased potassium, copper and sodium, while calcium and zinc increased significantly up to the intermediate stage, then declined toward the late stage of maturity. Maturity did not affect the magnesium, phosphorus, manganese and iron contents of the forage. Ruminal degradability of CP at $48,72,96$ and 120 incubation hour decreased significantly with maturity, with no effect on all other incubation times for DM and CP. Maturity significantly decreased the soluble fraction (a) of DM, with no significant effect on other fractions of DM and CP. Effective degradability (\%) of DM and CP decreased with maturity when the rate of passage increased from $2 \%$ to $8 \%$. Napier forage should be harvested before maturity to retain its high nutrient content, and the degradability of DM and $\mathrm{CP}$.
\end{abstract}

Keywords: mineral composition, in sacco, dry matter, crude protein disappearance

\#Corresponding author: joseph.baloyi@univen.ac.za

\section{Introduction}

Currently, there is increasing demand for ruminant animal products owing to the growing population and improved livelihoods (Dastagiri, 2004). However, feed shortages and the poor quality of forage in the dry season are major production constraints in the smallholder livestock sector. Climate change, and economic and anthropogenic factors put pressure on conventional feeds to remain unaffordable; hence smallholder farmers are seeking affordable alternatives (Chakeredza et al., 2007). Pasture and fodder remain the cheapest forms of animal feed. The ideal pasture and fodder species should be high yielding and palatable, and contain adequate levels of highly digestible nutrients to satisfy the requirements of livestock (Kisitu, 2010).

Napier grass (Pennisetum purpureum), also known as Elephant grass, has been the most promising high-yielding fodder, giving DM yields that surpass most other tropical grasses (Ansah et al., 2010). It originates from sub-Saharan tropical Africa (Clayton et al., 2013) and has been introduced in most tropical and subtropical regions worldwide as forage. According to Mdziniso (2012), Napier grass is a tall perennial grass that grows to $2-5$ metres $(\mathrm{m})$ tall, rarely up to $7.5 \mathrm{~m}$, with leaves about $30-120$ centimetres $(\mathrm{cm})$ long and $1-5 \mathrm{~cm}$ broad.

The grass has been used by smallholder farmers in cut-and-carry feeding systems (Premaratne \& Premalal, 2006; Nyambati et al., 2010). Research consistently indicates that as Napier grass matures, the DM yield increases, while CP declines (Kramberger \& Klemencic, 2003; Bayble, 2007, Sultan et al., 2007, Ansah et al., 2010). Hence, the maturity stage of pasture grass at harvesting or grazing is considered a crucial management practice because this determines nutritional value of the grass (Jusoh et al., 2014). Information on the relationship between the quality and degradability of Napier grass at various stages of maturity is limited and is ultimately important for silage making. Therefore, the current study was aimed at 
determining the productivity, chemical composition and ruminal degradability of DM and CP of Napier grass harvested at three stages of maturity.

\section{Materials and Methods}

The study was conducted at University of Venda, School of Agriculture Experimental Farm, Thohoyandou (22 $58^{\prime} 32^{\prime \prime} \mathrm{S}, 30^{\circ} 26^{\prime} 45^{\prime \prime} \mathrm{E}$; altitude $596 \mathrm{~m}$ above sea level). Samples were analysed in the Animal Science Nutrition Laboratory, University of Venda. The average maximum and minimum temperatures are $31{ }^{\circ} \mathrm{C}$ and $18{ }^{\circ} \mathrm{C}$, respectively (Tadross et al., 2005). The area receives annual rainfall of $500 \mathrm{~mm}$, which falls predominantly in summer. The area is characterized by deep well-drained red clay soil (Soil Classification Working Group, 1991), and low organic carbon, and has a slightly acidic pH. Characteristics of this soil are summarized in Table 1. The trial was approved by University of Venda's Ethics Committee.

Table 1 Physical and chemical characteristics of representative soil sample before planting $(0-20 \mathrm{~cm}$ depth)

\begin{tabular}{lc}
\hline Parameters & Soil \\
\hline Clay \% & $>60$ \\
Density $(\mathrm{g} / \mathrm{ml})$ & 1.08 \\
Organic carbon \% & 3 \\
$\mathrm{pH}$ & 5.02 \\
Calcium $(\mathrm{g} / \mathrm{kg})$ & 0.83 \\
Magnesium $(\mathrm{g} / \mathrm{kg})$ & 0.32 \\
Nitrogen $(\mathrm{g} / \mathrm{kg})$ & 2.60 \\
Phosphorus $(\mathrm{g} / \mathrm{kg})$ & 0.01 \\
Potassium $(\mathrm{g} / \mathrm{kg})$ & 0.17 \\
Copper $(\mathrm{mg} / \mathrm{kg})$ & 21.90 \\
Manganese $(\mathrm{mg} / \mathrm{kg})$ & 47.00 \\
Zinc $(\mathrm{mg} / \mathrm{kg})$ & 3.20 \\
\hline
\end{tabular}

The study was conducted from April to July 2014. Daily data for weather (Table 2) during the experimental period were extracted from Agricultural Research Council - Institute for Soil, Climate and Water (ARC-ISCW) station at the University of Venda. The site was ploughed with a tractor, harrowed, then demarcated into six plots, each $4 \times 5 \mathrm{~m}$ in a completely randomised design. After land preparation, the plots were irrigated to field capacity. A basal fertilizer 2:3:2 (Nitrogen: Phosphorus: Potassium) was applied at the rate of $250 \mathrm{~kg} / \mathrm{ha}$, plus superphosphate at the rate of $300 \mathrm{~kg} / \mathrm{ha}$. Napier grass was planted manually at a spacing of $70 \mathrm{~cm}$ inter and intra rows using Napier cuttings with three nodes. At least two nodes were placed into the ground and above the ground at an angle of $30-45^{\circ}$. All the plots were irrigated manually with water pipes during the 12 weeks of the experiment. The irrigation regime was designed to supplement rainfall to maintain field capacity. Weeding was done manually immediately after the weeds started to grow.

Table 2 Rainfall, temperature and relative humidity recorded during the experimental period April-July 2014

\begin{tabular}{lccc}
\hline Month & Rainfall $(\mathrm{mm})$ & Temperature $\left({ }^{\circ} \mathrm{C}\right)$ & Relative humidity $(\%)$ \\
\hline April & 0.483 & 20.6 & 72.1 \\
May & 0.033 & 18.7 & 68.3 \\
June & 0 & 17.2 & 60.3 \\
July & 0.033 & 16.5 & 59.8 \\
\hline
\end{tabular}


The Napier grass leaf samples were cut at intervals of four weeks, namely at week 4 (early stage), week 8 (intermediate stage) and week 12 (late stage) after sprouting. Napier cuttings were sampled and taken for chemical analysis and ruminal degradability studies.

For production parameter data, the number of tillers and leaves were counted, and the height of the grass and the longest leaf length $(\mathrm{cm})$ were measured once every two weeks from the second week until the last cut of sample grass on the twelfth week. Four plants were randomly selected in the middle of each plot to avoid edge effect, and tagged for data collection. Dry biomass was measured on the twelfth week (late stage) after collecting the samples.

Approximately $1000 \mathrm{~g}$ of samples of whole Napier grass leaves were manually cut at random from the nodes using pruning scissors, and plucked by hand from each plot per stage of maturity. The grass was cut when the leaves were fully expanded at the early growing stage and at intervals of four weeks until the twelfth week after sprouting. During the sampling process, fodder leaves were cut into lengths of $1-3 \mathrm{~cm}$ using pruning scissors, and oven dried at $60^{\circ} \mathrm{C}$ for 48 hours $(\mathrm{h})$ to determine DM content (AOAC, 2005). The samples were milled to pass through a 2-mm screen. Ash content was determined by combusting at $550{ }^{\circ} \mathrm{C}$ overnight (AOAC, 2005). Nitrogen $(N)$ content was analysed with the Kjeldahl procedure (AOAC, 2005) and converted to $\mathrm{CP}$ as $\mathrm{N} \times 6.25$. Fat content was determined with the soxhlet fat extraction method described by AOAC (2005). ADF, NDF and ADL composition were determined according to the method of Van Soest et al. (1991). Phosphorus $(\mathrm{P})$, potassium $(\mathrm{K})$, calcium $(\mathrm{Ca})$, magnesium $(\mathrm{Mg})$, sulphur $(\mathrm{S})$, copper $(\mathrm{Cu})$, zinc $(\mathrm{Zn})$, manganese $(\mathrm{Mn})$ and iron $(\mathrm{Fe})$ were determined with inductively coupled plasma optical emission spectrometry (ICP-OES) (SOP, 2005).

Three mature Bonsmara steers were fitted with rumen cannulae of $8 \mathrm{~cm}$ internal diameter and were used to determine the DM and CP degradability profiles of Napier grass leaves harvested at the early, intermediate and late stages of plant maturity. During the experiment, the animals were housed in individual pens. They were fed commercial complete cattle finisher (Table 3) ad libitum, starting 21 days before the commencement of the incubation of bags. Clean drinking water was available in buckets throughout the whole experiment.

Table 3 Chemical composition of the commercial complete cattle finisher diet ${ }^{*}$

\begin{tabular}{lc}
\hline Composition & $\mathrm{g} / \mathrm{kg}$ \\
\hline Protein (min) & 120 \\
Calcium (max) & 8 \\
Phosphorus (min) & 3 \\
Moisture (max) & 120 \\
Fibre (max) & 200 \\
Fat (min) & 25 \\
Urea (max) & 1.25 \\
$\%$ Derived from urea & $29.9 \%$ \\
& $\mathbf{m g} / \mathbf{k g}$ \\
Monensin Na & 30 \\
Zinc bacitracin & 50 \\
\end{tabular}

*Supplied by Driehoek Feeds, Vaalwater, Waterberg, Limpopo, South Africa

Nylon bags $(12 \times 6 \mathrm{~cm}$, pore size $46 \mu \mathrm{m})$ duplicated per incubation time were filled with approximately $5 \mathrm{~g}$ Napier grass leaves samples collected at the early, intermediate and late stages of plant maturity. The bags were attached with plastic bands to flexible vinyl plastic tubes, approx. $40 \mathrm{~cm}$ long and of $6 \mathrm{~mm}$ outer diameter, and inserted into the rumen of the cannulated steers for incubations of $0,6,12,24,48,72,96$ and $120 \mathrm{~h}$. The bags were inserted at $0600 \mathrm{hrs}$ before the morning feeding time. After each incubation period, the bags were removed from the rumen and washed in running tap water without squeezing, until the water was clear. The zero hour incubation bags were washed without incubation in the rumen. The washed bags were dried in an oven at $60{ }^{\circ} \mathrm{C}$ for $48 \mathrm{~h}$, weighed, and the residues analysed for $\mathrm{N}$ content. Nutrient degradation was calculated as the difference between the amounts in the control sample and in the degraded residues. 
The degradability of DM and CP with time for each sample was described using the mathematical model of Ørskov \& McDonald (1979):

$$
\begin{gathered}
\mathrm{P}=\mathrm{a}+\mathrm{b}\left(1-\mathrm{e}^{-\mathrm{ct}}\right) \\
\text { Where } \mathrm{P}=\mathrm{DM} \text { disappearance at time } \\
\mathrm{t}, \mathrm{a}=\text { zero time intercept } \\
\mathrm{b}=\text { slowly degradable fraction } \\
\mathrm{c}=\text { rate of degradation }
\end{gathered}
$$

Potential degradability (PD) was estimated as $(a+b)$. Effective degradability (ED) was calculated at rumen fractional outflow rates $(k)$ of $0.02,0.05$ and 0.08 per hour according to Ørskov \& McDonald (1979):

$E D=a+b c /(k+c)$

The degradation constants were estimated with Neway Excel version 6 (The Rowett Research Institute, Aberdeen, UK). Production parameters, chemical composition, DM and CP disappearance, and degradation constants were subjected to analysis of variance using the general linear model of Minitab software version 17 (2014). Treatment means were compared using Tukey's procedure at $P<0.05$. The model was $Y_{i j}=\mu+M_{i}+\varepsilon_{i j}$; where, $Y_{i j}=$ is the observation; $\mu=$ overall mean; $M_{i}=$ effect of the ith stage of maturity and $\varepsilon_{\mathrm{ij}}=$ random error.

\section{Results}

The growth parameters of Napier grass at three stages of maturity are presented in Table 4 . The longest leaf length per plant and plant height differed $(P<0.01)$ at all three stages. The number of tillers and leaves per plant did not differ $(P>0.05)$. The longest leaf length per plant, plant height, number of leaves per plant and number of tillers increased with maturity of the grass. The cumulative biomass yield was 6.08 tons/ha for 12 weeks' growth.

Table 4 Production parameters of Napier grass at three stages of maturity

\begin{tabular}{lccccc}
\hline Stage of maturity & $\begin{array}{c}\text { Longest leaf } \\
\text { length/plant }(\mathrm{cm})\end{array}$ & $\begin{array}{c}\text { Plant height } \\
(\mathrm{cm})\end{array}$ & $\begin{array}{c}\text { Number of } \\
\text { leaves/plant }\end{array}$ & $\begin{array}{c}\text { Number of } \\
\text { tillers }\end{array}$ & $\begin{array}{c}\text { Biomass production } \\
(\text { tons/ha) }\end{array}$ \\
\hline Early & $63.3^{\mathrm{b}}$ & $27.7^{\mathrm{b}}$ & 70.6 & 9.4 & $\mathrm{nd}$ \\
Intermediate & $72.9^{\mathrm{ab}}$ & $42.8^{\mathrm{ab}}$ & 88.9 & 11.0 & $\mathrm{nd}$ \\
Late & $78.5^{\mathrm{a}}$ & $58.5^{\mathrm{a}}$ & 104.5 & 12.9 & 6.08 \\
SEM & 3.21 & 6.08 & 10.9 & 1.28 & \\
Significance & $* *$ & $* *$ & $\mathrm{NS}$ & $\mathrm{NS}$ & \\
\hline
\end{tabular}

${ }^{\star \star}: P<0.01 ;(\mathrm{NS})$ non-significant: $P>0.05$

ab Column means with different superscripts differ significantly at $P<0.05$

nd: not determined, cm: centimetres; SEM: standard error mean

The chemical composition ( $\mathrm{g} / \mathrm{kg} \mathrm{DM}$ ) of Napier grass leaves at three stages of maturity is presented in Table 5. The DM content increased $(P<0.01)$ with maturity, while $\mathrm{CP}$ and fat content decreased $(P<0.01$ and $P<0.05$ respectively), with no effect $(P>0.05)$ on, ash, NDF, ADF and ADL. 
Table 5 Chemical composition $(\mathrm{g} / \mathrm{kg})$ of Napier grass leaves harvested at three stages of plant maturity

\begin{tabular}{lccccccc}
\hline Stage of maturity & DM & CP & Fat & Ash & NDF & ADF & ADL \\
\hline Early & $244.0^{\mathrm{c}}$ & $158.0^{\mathrm{a}}$ & $36.3^{\mathrm{a}}$ & 75.4 & 709.7 & 384.2 & 32.4 \\
Intermediate & $277.9^{\mathrm{b}}$ & $140.4^{\mathrm{b}}$ & $34.3^{\mathrm{ab}}$ & 77.1 & 685.6 & 370.0 & 35.2 \\
Late & $330.5^{\mathrm{a}}$ & $131.6^{\mathrm{b}}$ & $32.5^{\mathrm{b}}$ & 75.4 & 696.7 & 381.0 & 39.1 \\
SEM & 6.26 & 3.07 & 0.93 & 2.75 & 7.45 & 6.00 & 4.56 \\
Significance & $* *$ & $* *$ & $*$ & NS & NS & NS & NS
\end{tabular}

${ }^{* *}: P<0.01$

${ }^{*} P<0.05 ;$ NS: non-significant: $P>0.05$.

abc Column means with different superscripts differ significantly at $P<0.05$.

DM: dry matter, CP: crude protein, ADL: acid detergent lignin, ADF: acid detergent fibre, NDF: neutral detergent fibre, SEM: standard error of mean

The macro-mineral $(\mathrm{g} / \mathrm{kg})$ and micro-mineral $(\mathrm{mg} / \mathrm{kg})$ compositions of Napier grass leaves harvested at three stages of plant maturity are presented in Table 6 . Stage of maturity had an effect on $\mathrm{Ca}, \mathrm{Na}$ and $\mathrm{Zn}(P$ $<0.05)$, as well as $\mathrm{Cu}$ and $\mathrm{K}(P<0.01)$. No effects $(P>0.05)$ were observed for $\mathrm{Mg}, \mathrm{P}, \mathrm{Mn}$ and Fe at three stages of maturity. $\mathrm{Mg}$ increased from 1.82 to $2.29 \mathrm{~g} / \mathrm{kg}$ while $\mathrm{K}, \mathrm{Na}, \mathrm{P}$ and $\mathrm{Cu}$ decreased from 19.94 to $16.09 \mathrm{~g} / \mathrm{kg}, 0.63$ to $0.37 \mathrm{~g} / \mathrm{kg}, 1.34$ to $1.08 \mathrm{~g} / \mathrm{kg}$ and 9.51 to $6.78 \mathrm{mg} / \mathrm{kg}$, respectively, with progressed maturity (from early to late).

Table 6 Macro-mineral $(\mathrm{g} / \mathrm{kg})$ and micro-mineral $(\mathrm{mg} / \mathrm{kg})$ composition of Napier grass leaves harvested at three stages of plant maturity

\begin{tabular}{|c|c|c|c|c|c|c|c|c|c|}
\hline \multirow{2}{*}{ Stage of maturity } & \multicolumn{5}{|c|}{ Macro minerals } & \multicolumn{4}{|c|}{ Micro minerals } \\
\hline & $\mathrm{Ca}$ & $\mathrm{Mg}$ & $\mathrm{K}$ & $\mathrm{Na}$ & $P$ & $\mathrm{Zn}$ & $\mathrm{Cu}$ & $\mathrm{Mn}$ & $\mathrm{Fe}$ \\
\hline Early & $2.8^{\mathrm{b}}$ & 1.8 & $19.9^{\mathrm{a}}$ & $0.6^{\mathrm{a}}$ & 1.34 & $22.3^{\mathrm{a}}$ & $9.5^{\mathrm{a}}$ & 149.2 & 287.0 \\
\hline Intermediate & $3.4^{\mathrm{a}}$ & 2.2 & $17.4^{\mathrm{b}}$ & $0.6^{\mathrm{ab}}$ & 1.15 & $17.7^{\mathrm{b}}$ & $7.7^{\mathrm{b}}$ & 173.0 & 632.1 \\
\hline Late & $3.0^{a b}$ & 2.3 & $16.1^{\mathrm{b}}$ & $0.4^{\mathrm{b}}$ & 1.08 & $19.9^{\mathrm{ab}}$ & $6.8^{\mathrm{b}}$ & 169.3 & 398.9 \\
\hline SEM & 0.14 & 0.13 & 0.69 & 0.06 & 0.11 & 0.91 & 0.41 & 7. 68 & 135.1 \\
\hline Significance & * & NS & ** & * & NS & * & ** & NS & NS \\
\hline
\end{tabular}

$\star *: P<0.01$

${ }^{*}: P<0.05 ;$ NS: non-significant: $P>0.05$

${ }^{\mathrm{ab}}$ Column means with different superscripts differ significantly at $P<0.05$.

Ca: calcium, Mg: magnesium, K: potassium, Na: sodium, P: phosphorus, Zn: zinc, Cu: copper, Mn: manganese, Fe: iron SEM: standard error of mean

In sacco DM and CP disappearance (\%) of Napier grass leaves harvested at three stages of maturity are presented in Table 7. As expected, the disappearance of DM and CP increased with escalating time of incubation, but decreased with advanced stages of maturity. Ruminal degradability of CP decreased $(P$ $<0.05$ ) with maturity at $48,72,96$ and 120 incubation $\mathrm{h}$, while there were no differences for DM and CP at all other incubation times. 
Table 7 In sacco dry matter and crude protein disappearance (\%) of Napier grass leaves harvested at three stages of plant maturity

\begin{tabular}{|c|c|c|c|c|c|c|c|c|c|}
\hline \multirow{2}{*}{ Content } & \multirow{2}{*}{ Stage of maturity } & \multicolumn{8}{|c|}{ Rumen incubation time (h) } \\
\hline & & 0 & 6 & 12 & 24 & 48 & 72 & 96 & 120 \\
\hline \multirow[t]{5}{*}{$\mathrm{DM}$} & Early & 19.1 & 23.3 & 26.4 & 33.9 & 41.5 & 50.3 & 55.9 & 65.2 \\
\hline & Intermediate & 17.0 & 23.3 & 25.5 & 29.3 & 36.6 & 42.1 & 49.2 & 55.1 \\
\hline & Late & 15.8 & 22.4 & 25.3 & 27.5 & 31.5 & 37.4 & 44.3 & 52.2 \\
\hline & SEM & 0.43 & 0.96 & 0.78 & 2.03 & 2.92 & 1.91 & 3.19 & 3.34 \\
\hline & Significance & NS & NS & NS & NS & NS & NS & NS & NS \\
\hline \multirow[t]{5}{*}{$\mathrm{CP}$} & Early & 13.1 & 14.4 & 16.5 & 21.9 & $26.4^{\mathrm{a}}$ & $36.1^{\mathrm{a}}$ & $42.8^{\mathrm{a}}$ & $54.6^{\mathrm{a}}$ \\
\hline & Intermediate & 12.2 & 13.4 & 15.5 & 20.7 & $25.2^{\mathrm{ab}}$ & $34.7^{\mathrm{a}}$ & $41.6^{\mathrm{ab}}$ & $49.4^{b}$ \\
\hline & Late & 12.0 & 11.7 & 14.7 & 19.0 & 23.7 & $31.0^{\mathrm{b}}$ & $39.4^{\mathrm{b}}$ & $46.0^{b}$ \\
\hline & SEM & 1.88 & 1.10 & 0.64 & 1.80 & 0.62 & 0.78 & 0.71 & 1.00 \\
\hline & Significance & NS & NS & NS & NS & * & $* *$ & * & ** \\
\hline
\end{tabular}

**: $P<0.01$

*: $P<0.05$; NS: non-significant: $P>0.05$

${ }^{a b}$ Column means with different superscripts differ significantly at $P<0.05$

DM: dry matter; CP: crude protein

The rumen degradability constants $a, b$ and $c$ at three rumen fractional outflow rates are given in Table 8. For DM, the $a$ and $c$ values decreased, while the $b$ value fluctuated with increased maturity. For CP, the $a$ value decreased, and the $b$ and $c$ values increased with increased maturity. However, effective degradability (\%) decreased with maturity, when the rate of passage was increased from $2 \%$ to $8 \%$ for DM and CP.

Table 8 Degradability constants and calculated effective degradability at three passage rates for dry matter and crude protein of Napier grass harvested at three stages of plant maturity

\begin{tabular}{|c|c|c|c|c|c|c|c|}
\hline \multirow{2}{*}{ Component } & \multirow{2}{*}{ Stage of maturity } & \multicolumn{3}{|c|}{ Degradability constants } & \multicolumn{3}{|c|}{ ED (\%) at three outflow rates } \\
\hline & & $a$ & $b$ & $c$ & $k=0.02$ & $k=0.05$ & $k=0.08$ \\
\hline \multirow[t]{5}{*}{ DM } & Early & $19.1^{\mathrm{a}}$ & 71.6 & 0.007 & $37.8^{\mathrm{a}}$ & $27.3^{\mathrm{a}}$ & $24.2^{\mathrm{a}}$ \\
\hline & Inter & $17.0^{\mathrm{b}}$ & 76.6 & 0.003 & $31.5^{\mathrm{b}}$ & $23.4^{\mathrm{b}}$ & $21.1^{\mathrm{b}}$ \\
\hline & Late & $15.8^{\mathrm{b}}$ & 69.8 & 0.027 & $29.0^{\mathrm{b}}$ & $21.6^{\mathrm{b}}$ & $19.5^{\mathrm{b}}$ \\
\hline & SEM & 0.42 & 10.7 & 0.016 & 1.02 & 0.75 & 0.53 \\
\hline & Significance & ** & NS & NS & ** & ** & ** \\
\hline \multirow[t]{5}{*}{$\mathrm{CP}$} & Early & 13.1 & 86.6 & 0.001 & $28.5^{\mathrm{a}}$ & 18.9 & 16.5 \\
\hline & Inter & 12.2 & 87.8 & 0.002 & $27.3^{\mathrm{ab}}$ & 18.0 & 15.6 \\
\hline & Late & 12.0 & 88.0 & 0.002 & $24.8^{\mathrm{b}}$ & 16.7 & 14.8 \\
\hline & SEM & 1.89 & 1.83 & 0.0003 & 0.624 & 0.76 & 1.00 \\
\hline & Significance & NS & NS & NS & ** & NS & NS \\
\hline
\end{tabular}

${ }^{\star *}: P<0.01$

$*: P<0.05$; (NS) non-significant: $P>0.05$

${ }^{a b}$ Column means with different superscripts differ significantly at $P<0.05$

DM: dry matter, CP: crude protein, a: soluble fraction (\%), $b$ : insoluble but potentially degradable fraction (\%), c: outflow rate of degradation $\left(\mathrm{h}^{-1}\right)$, and $k$ : rumen outflow rate $\left(\mathrm{h}^{-1}\right)$ 


\section{Discussion}

Growth parameters play a vital role in enhancing fodder yield (Imran et al., 2007). High correlations between production parameters such as plant height, leaf length and biomass yield have been reported (Tessema et al., 2003; Ndikumana \& Kamidi, 2006; Imran et al., 2007; Nyambati et al., 2010). In the present study, leaf length, plant height, number of leaves and number of tillers per Napier grass plant increased with maturity. As expected, in the present, study linear development of longest leaf length per plant with maturity was observed. Plant height increased by approximately $53 \%$ from early to late stage. These results agree with those of Ansah et al. (2010), who reported increased plant height with increase in harvest days. However, in this study it was observed that with the increase in the stage of maturity, the greater the number of leaves produced from the newly emerging tillers. These results agree with those of Amin (2011), who reported that the number of leaves of maize fodder plant increased with maturity. The number of tillers per plant increased with grass maturity as the number of tillers developed. When the plants approached maturity, numerous fine branches appeared, growing out from the leaf axils of the main stems (Wilsie \& Takahashi, 1934). This observation agrees with the results of Ansah et al. (2010).

The biomass yield obtained in the present study was higher than the results of Katuromunda (2010), who reported fodder DM yield of $5.93 \mathrm{t} / \mathrm{ha}$ after 11 weeks. The differences in DM yields could be attributed to varying cutting height, soil and climatic conditions (Zewdu et al., 2003).

Plant maturity is considered the primary factor that affects the nutritive value of forages. A number of factors affect the rate of change in nutrient composition with advancing plant development and maturity stages. These factors include plant type, climate, season, weather, soil type and fertility, soil moisture, leaf stem ratio, physiological and morphological characteristics, and may vary with annuals versus perennials, grasses versus legumes, etc. (Kilcher, 1981).

In the present study, the DM content increased as the grass matured, and higher DM was observed at the late stage of maturity. Kramberger \& Klemencic (2003), Bayble (2007) and Ansah et al. (2010) reported that the DM content increased as Napier grass maturity increased. As expected, CP was highest in the early stage compared with the intermediate stage and late stage. This could be attributed mainly to dilution of the $\mathrm{CP}$ contents of the forage crops by the rapid accumulation of cell wall carbohydrates at the later stages of growth (Van Soest, 1994). It was observed that the CP level decreased by $16 \%$ from early to late stage. CP content serves as an important indicator of fodder quality. In other studies, the CP content of Napier grass also decreased with maturity (Kramberger \& Klemencic, 2003; Bayble, 2007; Sultan et al., 2007; Ansah et al., 2010; Jusoh et al., 2014). In the present study, despite the decline in CP content with increasing stage of maturity, the final concentration exceeded the minimum CP level $(7.5 \%)$ required for rumen function (Jusoh et al., 2014). This indicated the possibility of improving the feeding of animals in tropical regions by planting Napier grass, thus enhancing the quality of nutrients supplied to animals.

In the present study, fat content decreased with maturity. Similar results were observed by Karabulut et al. (2006). Conversely, studies by Kamalak et al. (2005) and Kanak et al. (2012) showed increased fat content with progressing stages of maturity. Generally, ash content gives an indication of the minerals present in the sample. In contrast with the findings of the present study, Aganga et al. (2005) and Kanak et al. (2012) reported increased ash content with stage of maturity.

In the present study, the NDF and ADF contents decreased from early to intermediate and then increased at the late stage. In contrast, Aganga et al. (2005), Ansah et al. (2010) and Salamone et al. (2012) reported that the NDF content rose consistently as forage maturity increased. Results for the present study were higher than the NRC recommendations for NDF and ADF contents of 300 and $190 \mathrm{~g} / \mathrm{kg} \mathrm{DM}$ for a ration, respectively. The findings for ADL agree with the studies of Bayble (2007) and Aganga et al. (2005). Bayble (2007) and Aganga et al. (2005) observed increased ADL with progressive stages of maturity. The late stage had the highest lignin content, implying that though Napier grass had high DM, the high lignin content would bind the cellulose and hemicellulose and prevent them from being digested and utilized efficiently by the rumen microbes (Ansah et al., 2010). Therefore, forages with lower ADL concentrations are more desirable.

Aganga et al. (2004) observed fluctuations of all individual major and minor minerals with plant maturity. However, the observed decline in Ca content with maturity was reported by Kariuki (1989) and Kariuki et al. (1999). In the present study, the Ca concentration of Napier grass at all stages of maturity was adequate for maintenance, growth and lactation in sheep (1.2-2.6 g/kg) (ARC, 1980; McDowell et al., 1993; Khan et al., 2006). The Mg concentration was adequate for grazing animals, although early lactation ruminants require $2 \mathrm{~g} / \mathrm{kg}$ (Gill et al., 2004). While the $\mathrm{K}$ concentration was above the $8 \mathrm{~g} / \mathrm{kg}$ recommended for grazing animals at all stages of maturity, it may not meet the requirements $(10 \mathrm{~g} / \mathrm{kg})$ for high-producing cows, under stress such as hear stress (Mirzaei, 2012). Similarly, $\mathrm{Na}$ concentration was lower than the recommended range (1-4 g/kg) for growing and finishing ruminants by Underwood (1981) and Gill et al. (2004). In addition, natural forages with a deficiency of Na have been reported in many regions of the world (Pastrana et al., 1991; Areghoere, 2002). P concentration was lower than the critical requirement of $1.9 \mathrm{~g} / \mathrm{kg}$ 
for growing and finishing beef cattle (Gill et al., 2004). However, Kariuki (1989), Kariuki et al. (1999) and Suttle (2010) observed that P content of Napier grass decreased with maturity.

$\mathrm{Zn}$ concentration at all stages of maturity was within the recommended range of $12-20 \mathrm{mg} / \mathrm{kg}$, which is adequate for growing ruminants (ARC, 1980; Gill et al., 2004). Cu concentration in the present study decreased with maturity. It is commonly suggested that the dietary requirements of ruminants for $\mathrm{Cu}$ range from 8 to $14 \mathrm{mg} / \mathrm{kg}$ (NRC, 1984; Gill et al., 2004; Khan et al., 2006). Mn concentration in the present study at all stages of maturity exceeded the recommended levels of $20 \mathrm{mg} / \mathrm{kg}$ for growing and finishing cattle and 40 $\mathrm{mg} / \mathrm{kg}$, the critical level of dietary Mn (Gill et al., 2004). In this investigation, Fe concentration was above the level of $50 \mathrm{mg} / \mathrm{kg}$ proposed as adequate for grazing animals (McDowell, 1985; Gill et al., 2004; Khan et al., 2005). Little information has been found regarding mineral composition of Napier grass at three stages of maturity.

The decline in DM and $\mathrm{CP}$ rumen degradability with plant maturity has been reported widely (Aufrère et al., 2003; Yu et al., 2004; Rodrigues et al., 2004; Silva et al., 2008; Belachew et al., 2013; Ribeiro Junior et al., 2014). This reduction in disappearance could be explained by the decrease in protein content and increase in ADL content of grass with maturity. The disappearance of the DM contents in the leaves by the end of $48 \mathrm{~h}$ of incubation, generally considered equivalent to digestibility (Ehargava \& Ørskov, 1987) and being the mean retention time of fibrous feeds in ruminants (Kimambo \& Muya, 1991), revealed that Napier grass had less than $50 \%$ DM loss at all stages of maturity.

The high degradability of Napier grass leaves suggests that very low proportions of the $a$ and $b$ components were degraded beyond the rumen, as was supported by Aufrère et al. (2003). Therefore, the exact rate of passage is important for estimating effective degradability and the amount of undegraded protein passing to the small intestine (Mghen et al., 1996). The late stage of maturity recorded the highest outflow rate for DM and CP. This may explain the greater voluntary feed intake (Kusmartono et al., 1997). However, Ørskov \& McDonald (1979) showed that with higher outflow rates, less is degraded. In the present study, the reduction in degradability was much greater when the rate of passage was increased from $2 \%$ to $8 \%$ and also when the grass matured. These results are in agreement with Baloyi et al. (2008), who observed a decrease in DM and CP with advanced stage of maturity of Cowpea and Silverleaf desmodium forage legumes.

\section{Conclusion}

The cultivation of Napier grass is recommended to ensure a continuous supply of quality feed for ruminants. The findings indicate that the stage of harvesting is critical to obtaining high quality forage. Napier forage should be harvested before maturity to retain its high nutrient content, and the degradability of DM and protein. However, in vivo studies are necessary to evaluate the effect of change in nutritive value with maturity on specific nutrient digestibility and animal performance.

\section{Acknowledgement}

The authors gratefully acknowledge National Research Foundation (Grant number: 103596) for its financial support and ARC-ISCW for providing them with weather data.

\section{Authors' Contributions}

Conception and design of experiment was done by all authors (MDR, FF and JJB). MDR conducted the experiment and analysed data. All authors participated in interpretation of results and writing and integration of the manuscript. Critical revision and final approval of version to be published was also done by all authors.

\section{Conflict of interest declaration}

Authors confirm that there were no conflicts of interest.

\section{References}

Aganga, A.A., Omphile, U.J., Thema, T. \& Baitshotlhi, J.C. (2005) Chemical composition of Napier grass (Pennisetum purpureum) at different stages of growth and Napier grass silages with additives. J. Biol. Sci. 5 (4):493-496.

Amin, M.E.H., 2011. Effect of different nitrogen sources on growth, yield and quality of fodder maize (Zea mays L.). J. Saudi Soc. Agric. Sci. 10(1):17-23.

Ansah, T., Osafo, E.L.K. \& Hansen, H.H., 2010. Herbage yield and chemical composition of four varieties of Napier (Pennisetum purpureum) grass harvested at three different days after planting. Agric. and Biol. J. of North Am. 1 (5):923-929. 
AOAC, 2005. Official methods of analysis (16th ed.). Association of Official Analytical Chemists Inc., Washington DC, USA. pp. 210-240.

ARC, 1980. The nutrients requirements of ruminant livestock (4 $4^{\text {th }}$ ed.). CAB International, Wallingford. Aregheore, E.M., 2002. Voluntary intake and digestibility of fresh, wilted and dry Leucaena (Leucaena leuco chepala) at four levels to a basal diet of guinea grass (Panicum maximum). Asian-Aust. J. Anim. Sci. 15:1139-1146.

Aufrère, J., Graviou, D. \& Demarquilly, C., 2003. Ruminal degradation of protein of cocksfoot and perennial ryegrass as affected by various stages of growth and conservation methods. Anim. Res. 52:245-261.

Baloyi, J.J., Ngongoni, N.T. \& Hamudikuwanda, H., 2008. Chemical composition and ruminal degradability of Cowpea and Silverleaf desmodium forage legumes harvested at different stages of maturity. Trop. and Subtrop. Agroecosyst. 8:81-91.

Bayble, T., Melaku, S. \& Prasad, N.K., 2007. Effects of cutting dates on nutritive value of Napier (Pennisetum Purpureum) grass planted sole and in association with Desmodium (Desmodium intortum) or Lablab (Lablab purpureus). Liv. Res. Rural Dev. 19, Article \#11.

Belachew, Z., Yisehak, K., Taye, T. \& Janssens, G.P.J., 2013. Chemical composition and in sacco ruminal degradation of tropical trees rich in condensed tannins. Czech J.Anim. Sci. 58 (4):176-192.

Chakeredza, S., Hove, L., Akinnifesi, F.K., Franzel, S., Ajayi, O.C. \& Sileshi, G., 2007. Managing fodder trees as a solution to human-livestock food conflicts and their contribution to income generation for smallholder farmers in southern Africa. Nat. Resour. Forum. 31:286-296.

Clayton, W.D., Govaerts, R., Harman, K.T., Williamson, H. \& Vorontsova, M., 2013. World checklist of Poaceae. Richmond, UK: Royal Botanic Gardens, Kew.

Dastagiri, M.B., 2004. Demand and supply projections for livestock products in India. National. Center. Agric. Econ. \& Policy. Res. Policy Paper 21.

Ehargava, P.K. \& Ørskov, E.R., 1987. Manual for the use of nylon bag technique in the evaluation of feedstuff. FEED, Feed Evaluation and Experimentation Development Services. The Rowett Research Institute, Bucksburn, Aberdeen, Scotland.

Gill, W., Lane, C., Neel, J., Fisher, A., Bates, G. \& Joines, D., 2004. Mineral nutrition of beef cattle. The University of Tennessee.

Imran, M., Khan, S., Khalid, R., Gurmani, Z.A., Bakhsh, A., Masood, M. \& Sultani, M.I., 2007. Performance of different millet cultivars for fodder production under rainfed conditions of Islamabad. Sarhad J. Agric. 23 (2):281-284.

Jusoh, S., Alimon, A.R. \& Kamiri, M.S., 2014. Agronomic properties, dry matter production and nutritive quality of guinea grass (Megathrysus maximus) harvested at different cutting intervals. Malaysian $\mathrm{J}$. Anim. Sci. 17 (2):31-36.

Kamalak, A., Canbolat, O., Yavuz, G., Erol, A. \& Ozay, O., 2005. Effect of maturity stage on chemical composition, in vitro and in situ dry matter degradation of tumbleweed hay (Gundelia tournefortii L.). Small Rumin. Res. 58 (2):149-156.

Kanak, A.R., Khan, M.J., Debi, M.R., Pikar, M.K. \& Aktar, M., 2012. Nutritive value of three fodder species at different stages of maturity. Bangladesh J. Anim. Sci. 41 (2):90-95.

Karabulut, A., Canbolat, O. \& Kamalak., A., 2006. Effect of maturity stage on the nutritive value of birdsfoot trefoil (Lotus Corniculatus L) Hays. Lotus Newsletter. 36 (1):11-21.

Kariuki, J.N., 1989. Evaluation of two Napier grass cultivars (Pennisetum Purpureum) under irrigation at different stages of growth. MSc (Animal Production) thesis, University of Nairobi, Kenya.

Kariuki, J.N., Tamminga, S., Gitau, G.K., Gachuiri, C.K. \& Muia, J.M.K., 1999. Performance of Sahiwal and Friesian Heifers fed on Napier Grass supplemented with graded levels of lucerne. S. Afr. J. Anim. Sci. 29 (1):1-10.

Katuromunda, S., 2010. Improvement in nutrient quality of cattle diet and manure in urban and peri-urban areas. PhD thesis. Makerere University, Uganda.

Khan, Z.I., Ashraf, M., Hussain, A. \& McDowell, L.R., 2006. Concentrations of minerals in milk of sheep and goats grazing similar pastures in a semiarid region of Pakistan. Small Rumin. Res. 65:274-278.

Khan, Z.I., Hussain, I.A., Ashraf, M., Valeem, E.E. \& Javed, I., 2005. Evaluation of variation of soil and forage minerals in pasture in a semiarid region of Pakistan. Pakistan J. Bot. 37:921-931.

Kilcher, M.R., 1981. Plant development, stage of maturity and nutrient composition. J. Range Manage. 34:363-364.

Kimambo, A.E. \& Muya, H.M.H., 1991. Rumen degradation of dry matter and organic matter of different parts of banana plant. Liv. Res. Rural Dev. 3, Article \#3.

Kisitu, B., 2010. Growing fodder for livestock: Calliandra and Elephant grass. TECA-FAO.

Kramberger, B. \& Klemencic, S., 2003. Effect of harvest date on the chemical composition and nutrient value of Ceratium Holosteoides. Grass \& Forage Sci. 58:12-16. 
Kusmartono, Shimada, A. \& Barry, T.N., 1997. Rumen digestion and rumen outflow rate in deer fed fresh chicory (Cichorium intybus) or perennial ryegrass (Lolium perenne). J. Agri. Sci. 128:87-94.

McDowell, L.R., 1985. Nutrition of grazing ruminants in warm climates. Academic Press, New York, pp. 443

McDowell, L.R., Conrad, J.H. \& Hembry, F.G., 1993. Minerals for grazing ruminants in tropical regions. University of Florida, Gainseville.

Mdziniso, M.P., 2012. Effect of carbohydrate sources on fermentative characteristics and chemical composition of Napier grass (Pennisetum purpureum) Silage. BSc (Animal Science) thesis, University of Swaziland, Swaziland.

Mghen, D.M., Hvelplund, T. \& Weisbjerg, M.R., 1996. Rumen degradability of dry matter and protein in tropical grass and legume forages and their protein values expressed in the AAT-PBV protein evaluation system. In: Ndikumana J, de Leeuw, P. (eds). Sustainable feed production and utilization of smallholder livestock enterprises in sub-Saharan Africa. Proceedings of the Second African Feed Resources Network (AFRNET), Harare, Zimbabwe, 6-10 December 1993. AFRNET (African Feed Resources Network), Nairobi, Kenya.

Minitab, 2014. Minitab statistical software version 17. Minitab Inc., State College, Pennsylvania, USA.

Mirzaei, F., 2012. Minerals profile of forages for grazing ruminants in Pakistan. Open J. Anim. Sci. 2 (3):133141.

Ndikumana, J. \& Kamidi, R.E., 2006. Regional evaluation of agronomic performance and nutritive quality of accessions of Pennisetum purpureum and its hybrids with Pennisetum typhoides in sub-Saharan Africa. International Livestock Research Institute. Nairobi, Kenya

Neway Excel Computer Programme Version 6 - A utility for processing data of feed degradability and in vitro gas production. International Feed Resources Unit, The Rowett Research Institute, Aberdeen, UK.

NRC, 1984. Nutrient requirements of domestic animals. Nutrient requirements of sheep (6th ed.). National Academy of Science, Washington DC, USA.

Nyambati, E.M., Muyekho, F.N., Onginjo, E. \& Lusweti, C.M., 2010. Production, characterization and nutritional quality of Napier grass (Pennisetum purpureum (Schum.)) cultivars in Western Kenya. Afri. J. Plant Sci. 4 (12):496-502.

Ørskov, E.R. \& McDonald, I., 1979. The estimation of protein degradability in the rumen from incubation measurements weighted according to the rate of passage. J. Agric. Camb. 92:499-503.

Pastrana, R., McDowell, L.R., Conrad, J.H. \& Wilkinson, N.S., 1991. Mineral status of sheep in the Paramo Region of Colombia. II. Trace Minerals. Small Rumin. Res. 5:23-34.

Premaratne, S. \& Premalal, G.G.C., 2006. Hybrid Napier (Pennisetum purpureum X Pennisetum americarnum) VAR. CO-3: A resourceful fodder grass for dairy development in Sri Lanka. J. Agric. Sci. $2(1): 22-33$.

Ribeiro Junior, G.O., Velasco, F.O., Faria Júnior, W.G., Teixeira, A.M., Machado, F.S., Magalhães, F.A., Jayme, D.G. \& Gonçalves, L.C., 2014. in situ degradation kinetic of Andropogon Gayanus grass silages harvested at three stages of maturity. Braz. J. Vet. \& Anim. Sci. 66 (6):1883-1890.

Rodrigues, A.L.P., Sampaio, I.B.M., Carneiro, J.C., Tomich, T.R. \& Martins, R.G.R., 2004. In situ degradability of dry matter of tropical forages obtained at different times of cut. Braz. J. Vet. \& Anim. Sci. 56:658-664.

Salamone, A.M., AbuGhazaleh, A.A. \& Stuemke, C., 2012. The effects of maturity and preservation method on nutrient composition and digestibility of master graze. J. Anim. Res. \& Tech. 1 (1):13-19.

Silva, L.F.P., Cassoli, L.D., Roma Junior, L.C., Rodrigues, A.C.O. \& Machado, P.F., 2008. In situ degradability of corn stover and Elephant grass harvested at four stages of maturity. Sci. Agri. 65:595603.

Soil Classification Working Group, 1991. Soil classification: A taxonomic system for South Africa. Memoirs on the Agricultural Natural Resources of South Africa No. 15. Dept. of Agric. Devel., Pretoria.

SOP, 2005. Standard operation procedure, Elemental analysis of solution samples with inductively coupled plasma optical emission spectrometry. Soil and Plant Analysis Laboratory. University of WisconsinMadison. pp. 2-4.

Sultan, J.I., Rahim, I., Nawaz, H. \& Yaqoob, M., 2007. Nutritive value of marginal land grasses of northern grasslands of Pakistan. Pak. J. Bot. 39:1071-1082.

Suttle, N., 2010. Mineral Nutrition of Livestock (4th ed.). CABI. Wallingford, UK.

Tadross, M., Jack, C. \& Hewingtson, B., 2005. On RCM-based projections of change in southern African summer climate. Geophys. Res. Lett. 32, L23713.

Tessema, Z., Bears, R.M.T. \& Yami, A., 2003. Effect of plant height at cutting and fertilizer on growth of Napier grass (Pennisetum purpureum). Trop. Sci. 42:57-61.

Underwood, E.J., 1981. The mineral nutrition of livestock (2nd ed.). Commonwealth Agricultural Bureaux, Slough. 
Van Soest, P.J., 1994. Nutritional ecology of the ruminant. Comstock Publishing Associates. A division of Cornell University Press, Ithaca and London.

Van Soest, P.J., Robertson, J.B. \& Lewis, B.A., 1991. Methods for dietary fibre, neutral detergent fibre and non-starch polysaccharides in relation to animal nutrition. J. Dairy Sci. 74:3583-3597.

Wilsie, C.P. \& Takahashi, M., 1934. Napier grass (Pennisetum purpureum): A pasture and fodder crop for Hawaii. Hawaii Exp. Station, Bulletin \#72.

Yu, P., McKinnon, J.J. \& Christensen, D.A., 2004. The ratios of degradation characteristics of forages in the rumen of dairy cows: Effect of variety and stage of maturity. J. Sci. Food \& Agric. 884:179-189.

Zewdu, T., Baars, R.M.T. \& Yami, A., 2003. Effect of Plant height at cutting and fertilizer on growth of Napier grass (Pennisetum purpureum). Trop. Sci. J. 43 (1):57-61. 